\title{
Satisfaction of Surgical Informed Consent and Associated Factors Among Women Undergone Obstetric and Gynecologic Surgery at Jimma Medical Center, Jimma, Oromia Region, Ethiopia 2020.
}

Tsegaw Biyazin Tesfa ( $\nabla$ tsegabiya54@gmail.com )

Jimma Univesity https://orcid.org/0000-0002-2906-2382

AYANOS TAYE

Jimma Institute of Health Sciences: Jimma University

YESHITILA BELAY

Jimma University, Institute of health

Research article

Keywords: Surgical Informed consent, Patient satisfaction, surgical patients

Posted Date: December 29th, 2020

DOl: https://doi.org/10.21203/rs.3.rs-134862/v1

License: (1) (i) This work is licensed under a Creative Commons Attribution 4.0 International License.

Read Full License 


\section{Abstract}

Background: Informed consent is a process in which a healthcare provider obtains permission from an individual before delivering a certain health intervention. Patient satisfaction towards informed consent process is one main indicator of patient experience on health care services and mirror image of quality health care. The objective of this study was to assess the level of women satisfaction towards surgical informed consent and its associated factors at Jimma Medical Center, Ethiopia, 2020.

Method: Facility based cross-sectional study was conducted from April 1 to May30, 2020 at Jimma Medical Center. A total of 372 surgical patients were selected using a systematic random sampling method. The collected data was coded, entered into Epi data version 3.1 and analyzed using SPSS version 25. Bivariate and multivariate regression was carrying out to determine the association between outcome variable and independent variable.

Result: A total of 372 study participants were interviewed and giving a response rate of $97.8 \%$. Of this majority respondents were $167(44.9 \%)$ between $28-37$ years old, married $310(83.3 \%)$, Urban residence $242(65.1 \%)$ and housewife 168 (45\%). Patients' satisfaction towards surgical informed consent was 43\%. Multivariate logistic regression analysis showed that residence (AOR: 2.279, 95\% Cl: 1.257-4.131), current referred history (AOR: 1.856, 95\% Cl: 1.033-3.337), language of the written consent form (AOR: 2.076, 95\% Cl: 1.143-3.773), time taken for informed consent provision (AOR: $5.227,95 \% \mathrm{Cl}: 2.499-$ 10.936) and patient to health provider relationship (AOR: $5.419,95 \% \mathrm{Cl}: 3.103-9.464)$ were positively associated with patient satisfaction.

Conclusion: In this study, the level of patient satisfaction towards surgical informed consent process was relatively low compared with previous studies. Health care professionals need to give emphasize on way of delivering informed consent, patients' need and obey a standard informed consent process with evidence based practice to improve patient satisfaction.

\section{Background}

Patients' surgical informed consent for the operation is one vital part of preoperative care (1). Informed consent is the process in which a healthcare provider obtains permission from an individual before delivering a certain health intervention such as therapy, treatment and surgery. It is agreement on propose surgery perform between patient with health care providers (2).

The process of informed consent contains more than signing a prescribed form. It involves basic elements including the nature of the procedure; reasonable of operation, alternatives to the proposed intervention; the relevant risks, benefits and uncertainties with sharing a satisfactory amount of information to the consenting individual, addressing their concerns, fears, questions and discussing possible outcomes $(3,4)$. However, the habitual informed consent form content of information didn't consider the patients' needs and right (5). 
Patient satisfaction has been defined as the degree of meeting between a patients' expectations of ideal care with their perception of the real care received $(6,7)$. It is an important measure of healthcare quality (8). Patient satisfaction towards informed consent is increase when offer the written informed consent combine with verbal informed consent information during the preoperative period (9). Satisfied patients are more likely to obey treatment, take an active role in their own care and continue using health care services, voluntary involvement in decision making and stays within a healthcare provider (10).

Common reasons for postoperative patients dissatisfaction and usual complain by surgical patients were deformities, scars, asymmetry and infections (11). It would have mitigated or reduce if proper and sufficient patient center preoperative informed consent delivered about indication of operation, alternative, advantage, consequence and complication of surgery.

The ultimate goal of offering surgical informed consent include improve client understanding of the proposed procedure, maintain trust between patient to healthcare providers, increase patient satisfaction and minimize litigation issues related to surgical procedure (3). However, the status of patient satisfaction towards informed consent provision still low, especially in African countries compare with high income country (12-16). It shows that value given to what patient expectation and as well type of service being patient to satisfy while provision of informed consent has huge variation at clinical area.

Generally; patients satisfaction depends on the difference between expectation and perception, so that it seems advisable to analyze in depth which aspects of the health services provide greatest satisfaction to surgical patients. The primary significant of this study shows the degree of patient satisfaction towards surgical informed consent provided and to know the factors which lead the patient dissatisfied.

\section{Methods}

\section{Study design \& setting}

A cross-sectional study was conducted in Jimma Medical Center located in Jimma town, Ethiopia. Jimma Medical Center is a referral hospital for the south west part of Ethiopia. It is a teaching tertiary hospital with four major clinical departments including internal medicine, surgery, pediatrics, and gynecology/obstetrics in which Fistula rooms are contained and also has other clinical departments, dentistry, ophthalmology, Orthopedics, psychiatry, Reproductive health center, dermatology and ART clinic. Obstetrics and gynecology wards had 76 available beds for postoperative care. Around 1,461 and 900 patients were undergone obstetric and gynecological related surgery within past six month respectively (the previous 6 month report). Averagely around 787 patients were done surgery within two month. The study period was from April 1 to May 30, 2020.

\section{Study participants}


Women who undergone obstetrics and gynecologic surgeries were study participants of this study. Surgical patients who undergone Ob-Gyn surgery age of 18 year old and above was include in this study. However, these women who had repeated surgery at the same admission, critically ill and known psychiatric illness were excluded from the study.

\section{Sample size determination}

The sample size was determined using single population proportion formula by considering $62 \%$ proportion $(P)$ which took from research done in Hawassa (17); with 95\% confidence interval (1.96); $a=0.05$ and $5 \%$ marginal of error. By adding a non-response rate of $5 \%$, the final sample size was 380 .

\section{Sampling technique}

Systematic sampling technique was employed to select study participant from 787 total two month surgical cases after determining the interval ( $\mathrm{K}$ value). The k-value was determined by dividing total two month surgical case (787) to the final sample size (380) that given approximately 2 . The first study participant was selected by simple random technique from the first two individual and then the next participant was chosen every two interval from the registration book until the final sample size reached.

\section{Data collection measurement tool}

The data collection measurement tool was adapted from different literatures developed for similar purpose $(4,12)$. The body questioners have six parts. The first part about general socio-demographic consist of 8 items, the second part deals with patient related factors consist 7 items; third one about service related factors consist 8 item, the fourth part deal with patient to healthcare provider relationship consist 9 items, adopted from validation of the patient to doctor relationship questionnaire (PDRQ-9) study done in German (19), the fifth part deal about patients' knowledge towards surgical informed consent and the last part deal about the satisfaction of surgical informed consent it contain 10 items with five Likert scale option (range from 1 completely dissatisfied to 5 completely satisfied). Data was collected using structured closed ended questionnaire. The data collection method was using interviewer administered questionnaire and document review. Two BSc and one MSc nurses were recruited as data collectors and supervisor respectively.

\section{Dependent Variable}

Satisfaction of surgical informed consent

\section{Independent Variables}


- Social-demographic characteristics: Age, educational status, occupation, marital status, income and residence.

- Patient related factors: Parity, knowledge, type of surgery, previous medical history and previous surgery.

- Health care providers related factors: Patient to health care provider relationship

- Service related factors: Referred history, language of the written consent form, profession who request informed consent, timing of consent, time taken to provide of informed consent, time taken to decision making and person who signed on informed consent.

\section{Operational definition \& definition of terms}

Surgical patients: mean elective-emergency surgery and obstetrics, gynecology patients who operated during the study period.

Patient satisfaction: define as meeting someone's expectations hence enjoyment from received services and product.

Satisfied: In this study refer study participants who have acquiring the overall satisfaction above mean satisfaction scores (33.3) on the given items to measure respondents' satisfaction (13).

Dissatisfied: In this study refer participants who have acquiring the overall satisfaction below mean score (33.3) on the given items to measure respondents' satisfaction.

Knowledge on surgical informed consent: about surgical informed consent if women answered knowledge questions with above mean score consider good knowledge otherwise having poor knowledge (18).

Patient to doctor relationship: The patient to doctor relationship can be seen as the perception of the patient concerning the caring shown by the doctor and the attitude and behavior of the doctor towards the patient. The PDRQ contain 9 items with yes/no option. When the patients choose greater than 7 items with yes response, considered as good PDR (19).

\section{Data analysis procedure}

The collected data was coded and entered to Epi data version 3.1 and exported to SPSS version 25. Hosmer and lemeshow test was done to confirm the model fitness; its p-value was 0.072; so the model has been fitted. Bivariate and Multivariate analysis were done between satisfaction of surgical informed consent and explanatory variables. In bivariate logistic regression the variables which had p-value less than 0.25 was considered as candidate variable for multivariable logistic analysis. In multivariable 
analysis those variables which had p-value less than 0.05 were considered as statistically significant with outcome variable. The finding of the data was presented by using tables, figures and graphs.

\section{Data Quality Assurance}

The questionnaire was initially prepared in English then translated to local language Afaan Oromo and Amharic, then translated back to English. Prior to actual data collection, pretesting of the questionnaire was conducted on $5 \%$ of the total samples ( 19 women) undergone surgery in Shenen Gibe Hospital. After that appropriate corrections and mandate the questionnaire were made. One day training was given for the supervisor and data collectors. During data collection period, the data was checked for completeness and consistency of information. Any error, ambiguity, incompleteness or other problems was addressed through communication with data collectors before beginning of the next day data collection activities. The reliability of the patients' satisfaction tool was done by using Cronbach Alpha, it was 0.83 .

\section{Results}

\subsection{Socio-demographic characteristics}

From total 380 samples, 372 study participants were involved directly in this study giving a response rate of $97.8 \%$. The majority study respondents were married $310(83.3 \%)$ and $167(44.9 \%)$ were between $28-37$ years with mean age of 29.5. Majority $182(48.9 \%)$ were Muslim, $267(70.1 \%)$ study participants were Oromo. The majority 242 (65.1\%) participants were living in Urban, 168 (45\%) were housewife, 291 $(78.2 \%)$ were literate and nearly half $47.1 \%$ had less than 1500 EB monthly income (Table 1 ).

\subsection{Patient related factors}

Among study participants half (52.2\%) of them were multipara. Around three fourth of study participants (74.5\%) had undergone emergency surgical procedure. Majority study participants $319(86 \%)$ underwent operation with reason of pregnancy related case followed by 20 (5.4\%) gynecological cancer, $12(3.2 \%)$ gynecological benign tumor and $11(3 \%)$ pelvic organ disorder. One hundred three $(27 \%)$ respondents had previous history of surgery, among those $60(58.3 \%)$ of them had once time surgical history while the rest $43(41.7 \%)$ patients had more than one time surgical history (Table 2)

\section{Respondents' knowledge on surgical informed consent}

Figure 1: Women knowledge on surgical informed consent at Jimma Medical Center, Jimma, Oromia Region, Ethiopia 2020.

Women were asked to assess their knowledge towards surgical informed consent. Majority $(77.1 \%)$ of women had poor knowledge; and the rest around one quarter $(22.9 \%)$ of them had good knowledge to wards surgical informed consent (Figure 1). 


\subsection{Service related factors}

Two hundred fifty eight (69.4\%) study participants were referred from other health facilities. Above half $62.9 \%$ women were responding that the consent form written with in their mother tongue. The majority $302(81.2 \%)$ study participants reported that surgical informed consent was taken by GP/resident, followed by obstetrician-gynecologists $44(11.8 \%)$ and nurse/midwives $26(7 \%)$. More than half 208 (56\%) respondents reported that they received informed consent counseling immediately before surgery. The consent form was signed by the patients themselves 352 (94.6\%) while the rest $20(5.4 \%)$ were signed by their relatives (Table 3).

\subsection{Healthcare provider related factors}

\subsubsection{Patient to health provider relationship}

Figure 2: Patient to health care providers' relationship status at JMC, Jimma, Ethiopia, 2020.

Women were asked to assess patient to health care providers while they received provision informed consent. Out of total interviewed study participants 179 (48 \%) of women had good patient to health providers' relationship (Figure 2).

\subsection{Women satisfaction on surgical informed consent}

Women were scored highest satisfaction value on three satisfaction measurement items; i.e. on awareness of benefit of operation, involvement in the discussion about operation and involvement in decision making its accounts $79.1 \%, 89.5 \%$ and $91.2 \%$ respectively. In contrast to this the respondents scored lowest satisfaction value on five patient satisfaction measurement items; i.e. on alternative of operation, chance to express opinions, the chance to ask questions, the amount of information provided about operation and the explanation about operation its accounts $24.7 \%, 30.1 \%, 33.3 \%, 44.9 \%$, and $46.2 \%$ respectively (Table 4)

Figure 3 : The overall mean satisfaction level of respondents on surgical informed consent at Jimma Medical center, Jimma, Ethiopia 2020.

Women were asked to assess their level of satisfaction with the SIC they received prior to their surgical procedure on a five-point scale. The finding of this study showed that $160(43 \%)$ of respondents were satisfied and the rest $212(57 \%)$ of respondents were dissatisfied on informed consent provision (Figure $6)$.

Factors associated with Satisfaction of informed consent 
In bivariate logistic regression 15 variables which had p-value less than 0.25 was considered as candidate variable for multivariate logistic analysis. These variables were age, educational status, residence, marital status, occupation, parity, type of surgery, referred history from other health facility, language of written consent form, timing of consent, time taken to provide informed consent, person signing the consent form, professional request the operation, knowledge to wards SIC and patient to healthcare providers relationships (Table 5).

In multivariable logistic analysis 5 variables had p-value less than 0.05 . These variables were residence, referred history from other hospital, language of written consent form, time spent while provided SIC and patient to healthcare provider relationship statistically significant with outcome variable (Table 6).

The result of multivariable logistic regression analysis showed that the respondents who came from urban setting 2.2 times (AOR: $2.279,95 \% \mathrm{Cl}$ : 1.257-4.131) more likely satisfied than those who came from rural residence. Respondents who haven't referred history from other health setting were 1.8 times (AOR: 1.856, 95\% Cl: 1.033-3.337) more likely satisfied towards provision of informed consent compared to those who have referred history from other health facility.

Women received written informed consent with their mother tongue were two times (AOR: $2.076,95 \% \mathrm{Cl}$ : 1.143-3.773) more likely satisfied towards informed consent than counterpart. Patients who had received information about surgical informed consent for 10 minutes duration were 5.2 times (AOR: $5.227,95 \% \mathrm{Cl}$ : 2.499-10.936) more likely satisfied on provision of informed consent than patients who have received the information for less than 5 minute.

Furthermore women had good patient to health care providers relationship were 5.4 times (AOR: 5.419, 95\% Cl: 3.103-9.464) more likely satisfied towards informed consent process than counterpart.

\section{Discussion}

The result of the study revealed that women satisfaction level towards surgical informed consent was $43 \%$ (95\% Cl: $38.2 \%$ to $48.7 \%$ ). The finding of this result in line with study done in Egypt and Eritrea its accounted $48.4 \%$ and $45 \%$ patients satisfied with SIC provision respectively

$(16,20)$. However this study finding of women satisfaction level lower than study conducted in Netherland, Israel, Ethiopia, Rwanda and Pakistan on patients satisfaction towards informed consent which accounted $80.8 \%, 80 \%, 62.1 \%, 67.4 \%$ and $48.9 \%$ respectively $(13,15,17,21,22)$. Patients' satisfaction towards provision of surgical informed consent varies from country to country; the possible reason might be due to health care service quality and patients flow rate variation.

The finding of this study showed women who came from urban residence were two times more likely satisfied towards informed consent process as compared to respondents who came from rural residence. It supported by study conducted in Eritrea; patients who came from urban settings were more satisfied on consent information compared to patients those who came from a rural setting (16). This might be due to 
the fact that the urban livings populations have been know patient autonomy and competent to raise questions for healthcare providers to told them about their current condition, progress and the plan of intervention that will be done.

According to this study finding; surgical patients who hadn't referred history from other health setting were 1.8 times more likely satisfied compared to those who had referred history from other health facility. The possible reason might be due to patients who had referred history from other health facility have be worries on their case or diseases because their case beyond the service given by local health facility and they came to seeking further investigation and intervention. They also have being anxious and stressful in new hospital environment and healthcare provider since they came from other hospital.

Women satisfaction on surgical informed consent was statistically significant with language of written informed consent. Women who received written informed consent with mother tongue were two times more likely satisfied towards informed consent than counterpart. It supported by study done in Switzerland the consent form written in a simple layman language and simpler wording improve patients' ability to understand the information provided and strongly associated with patients' satisfaction (12). Simply provision of information doesn't guarantee to say a patient understood what healthcare providers told to them unless we provided the information within their mother tongue due to the fact that patients belonged to various ethnic groups that speak different languages (17). This might be due to delivering of clear information to women within their mother tongue, lead them to easily understand the information given by health care providers and have being satisfied.

Furthermore, time spent while provision of surgical informed consent was positively associated with women satisfaction towards surgical informed consent. Patients who had received information about surgical informed consent for greater than 10 minutes time duration were 5 times more likely satisfied than patients who received the information for less than 5 minute. It support by study done in Nigeria revealed that; time spent in explaining surgery procedure and possible outcome could calm patients and reduce level of anxiety (23). This might be due to adequate time provided to women during informed consent process allow them to easily understand the information provision. When health care providers explaining proposed surgery with adequate time, then the women coped from their anxiety and they have been satisfied.

Furthermore women satisfaction towards informed consent was significantly associated with patient to health care provider relationship. According to this study the respondents who had good relationship with health care providers were 5.4 times more likely satisfied towards informed consent process than counterpart. It supported by study done in Netherland reported that a better perceived patient to doctor relationship was related to higher patient satisfaction (24). Similarly, study conducted in Australia revealed that patient centered health care service with effective communications skills result trust between patient and healthcare provider and improved patient satisfaction (25). This might be due to good patient to health care providers relationship build trust between them; then the patients have been ready to open their mind to receive the information provided by health care providers. 


\section{Limitation of the study}

Generalizability issue because of this study done on women who undergone on obstetrics and gynecologic related case it didn't address major surgery and other surgical case. Social desirability biases also other limitation on this study.

\section{Strength of the study}

The strength of this study; it used probable sampling technique and had high response rate.

\section{Conclusion}

According to this study finding the level of patient satisfaction with in the surgical informed consent services was relatively low compared with previous studies conducted in the country and other countries in the world. The patient satisfaction is one indicator of health service quality. Residence, language of written informed consent, time spent while provision of SIC, utilization of the recommend component of SIC and patient to healthcare provider relationship were the determinant factors for women satisfaction towards informed consent.

\section{Recommendation}

The Jimma Medical Center should develop informed consent form based on patient case to surgery department. Fixed and uninform printed consent form for all case is not valid it should be specific to patient and disease or case oriented.

Jimma Medical Center should prepare training session for health professionals to strength patient to health provider relationship and to improve way of delivering informed consent service.

Healthcare provider needs to give emphasis to their way of informed consent provision; patients need and follow standard informed consent guideline to come up with evidence based practice.

The health care providers should give enough time while provision of surgical informed consent to patients. It should not be just rush to signed consent form rather give adequate time and information until patients understood the information provided to them and ready themselves to decision making.

The forthcoming researcher should be emphasized the perspective of health care providers of surgical informed consent process.

\section{Abbreviations}


AOR: Adjusted odd Ratio; COR: Crude Odd Ratio; JMC: Jimma Medical Center, SIC: surgical informed consent.

\section{Declarations}

\section{Ethical approval and consent to participate.}

Ethical letter was obtained from institutional review board of Jimma University. After obtain the ethical review board support letter, it was submitted to Jimma Medical Center. Then after getting permission from the hospital, verbal consent was obtained from individual participants. Moreover, study participants were informing about aim of the study and the data used only research purpose. The data collection was done using anonymously to confirm the respondents' confidentiality. All the participants were told that their participation would be on voluntary basis and their information will be kept confidential.

\section{Consent of Publication}

Not applicable

\section{Availability of data and materials}

The datasets used for this study could be deposited in publicly available repositories where appropriate and upon reasonable request. All relevant raw data supporting the findings and conclusions of this study can also be freely available from the corresponding author through E-mail- tsegabiya54@gmail.com or with other means to any scientist wishing to use them for non-commercial purposes without breaching participant confidentiality upon reasonable request. There will not be any concern on ethical aspect for this as participant data was de-identified.

\section{Competing interests}

The authors declare that they have no competing interest

\section{Funding}

The fund of this research was obtained from Jimma University, Jimma, Ethiopia. The role of the funder was only providing the fund needed for this study

\section{Author's contribution}

TB: Develops proposal and the finial draft of the research.

AT: Participate in analyzing and interpreting the data, discussing the findings of the study and drafting the manuscript.

YB: Participate in analyzing and interpreting the data, discussing the findings of the study. All authors have read and approved the manuscript. 


\section{Author's information}

${ }^{1}$ Tsegaw Biyazin, ${ }^{2}$ Ayanos Taye and ${ }^{3}$ Yeshitila Belay

${ }^{1}$ corresponding author, Msc in maternity health nursing at Jimma University, ${ }^{2} \mathrm{MSc}$ in maternity health nursing, Assistance professor, PhD fellow, lecturer at Institute of health, faculty of health science, school of Nursing, Jimma University, Ethiopia and ${ }^{3}$ MSc in Adult health nursing, Assistance professor, lecturer at Institute of health, Faculty of health science, School of Nursing, Jimma University Ethiopia.

\section{Acknowledgement}

First, we would like give my special thanks goes to Jimma University for its contribution on financial support. Secondly, our heartfelt thanks go to Jimma Medical Center staffs, data collectors and study participants. Last but not least we would like to thanks also our colleagues for their heartfelt encouragement and support while we prepared this research.

\section{References}

1. Lee A V., Moriarty JP, Borgstrom C, Horwitz LI. What can we learn from patient dissatisfaction? An analysis of dissatisfying events at an academic medical center. J Hosp Med. 2010;5(9):514-20.

2. Lovegrove C, Mantori S, Shrotri N. Patient Satisfaction with Informed Consent on the Day of Surgery. Int J Surg. 2017;47(2017):S96.

3. Leclercq WKG, Keulers BJ, Scheltinga MRM, Spauwen PHM, Van Der Wilt GJ. A review of surgical informed consent: Past, present, and future. World J Surg. 2010;34(7):1406-15.

4. Rogers P, Lloyd S, Shetty D, Newell P, Gay D. Measuring patient satisfaction with the ct consent process: The comrade outcome measure. Imaging Med. 2013;5(6):505-13.

5. Meaza Birile. Perception about informed consent for surgical procedures as part of patient safety practice among service providers and patients in Addis Ababa hospitals. 2017;(October).

6. Aragon SJ, Gesell SB. A Patient Satisfaction Theory and Its Robustness Across Gender in Emergency Departments: A Multigroup Structural Equation Modeling Investigation. Am J Med Qual. 2003;18(6):229-41.

7. Mira JJ, Tomás 0 , Virtudes-Pérez M, Nebot C, Rodríguez-Marín J. Predictors of patient satisfaction in surgery. Surgery. 2009;145(5):536-41.

8. Warner DS, Sc B, Giannaris S, John R. Patient-Satisfaction Measures in Anesthesia. 2013;(2).

9. Trinh LN, Fortier MA, Kain ZN. Primer on adult patient satisfaction in perioperative settings. Perioper Med. 2019;8(1):1-13.

10. Getachew G, Berhe D. Why patients are dissatisfied on nursing care services at menelik hospital, addis ababa . J Innov Assoc. 2016;5(6):850-60.

11. Park BY, Kwon J, Kang SR, Hong SE. Informed Consent as a Litigation Strategy in the Field of Aesthetic Surgery. Arch Plast Surg. 2016;43(5). 
12. Ghulam, A. T., Kessler, M., Bachmann, L. M., Haller, U., \& Kessler TM. Patients' Satisfaction With the Preoperative Informed Consent Procedure in Switzerland. Mayo Clin Proc. 2006;81(3):307-312.

13. Bedforth NM, Hardman JG. Patient satisfaction with perioperative care among patients having orthopedic surgery in a university hospital. Local Reg Anesth. 2010;3:49-55.

14. Ar B, Me H, H VDH. Patient satisfaction with the quality of care in a primary health care setting in Botswana. 2011;53(2):170-5.

15. Leóntine I. DISSERTATION PATIENTS SATISFACTION WITH PERIOPERATIVE CARE AT OSHEN FING FAISAL HOSPITAL BY. 2017;(June).

16. Andemeskel YM, Elsholz T, Gebreyohannes G, Tesfamariam EH. Patient satisfaction with perioperative anesthesia care and associated factors at two National Referral Hospitals: a cross sectional study in Eritrea. BMC Health Serv Res. 2019;19(1):1-20.

17. Teshome M, Wolde Z, Gedefaw A, Tariku M, Asefa A. Surgical informed consent in obstetric and gynecologic surgeries: experience from a comprehensive teaching hospital in Southern Ethiopia. BMC Med Ethics. 2018;1-9.

18. N.Nurhusien YA\& BH. Knowledge and perception of surgical informed consent and associated factors among adult surgical patients in Gondar University Comprehensive and Specialized Hospital , Ethiopia. 2018;1-33.

19. Zenger M, Schaefert R, Van Der Feltz-Cornelis C, Brähler E, Häuser W. Validation of the patient-doctorrelationship Questionnaire (PDRQ-9) in a representative cross-sectional German population survey. PLoS One. 2014;9(3):1-8.

20. Mohamed AM, Ghanem MA, Kassem AA. Knowledge, perceptions and practices towards medical ethics among physician residents of University of Alexandria hospitals, Egypt. East Mediterr Heal J. 2012;18(9):935-45.

21. Jawaid M, Farhan M, Masood Z, Husnain SMN. Preoperative Informed Consent: Is It Truly Informed? Iran J Publ Heal. 2014; Vol. 41:25-30.

22. Abolfotouh MA, Adlan AA. Quality of informed consent for invasive procedures. Int J Gen Med. 2012;5:269-75.

23. Parvin R and Shahjahan M. KNOWLEDGE, ATTITUDE, AND PRACTICE OF E-HEALTH AMONG DOCTORS WORKING AT SELECTED PRIVATE HOSPITALS IN DHAKA, BANGLADESH Rehana Parvin BPT, MPH, Md Shahjahan MCPS, MD. 2016;(April 1995):1-11.

24. de Waard CS, Poot AJ, den Elzen WPJ, Wind AW, Caljouw MAA, Gussekloo J. Perceived doctor-patient relationship and satisfaction with general practitioner care in older persons in residential homes. Scand J Prim Health Care [Internet]. 2018;36(2):189-97. Available from: https://doi.org/10.1080/02813432.2018.1459229

25. Chandra S MM. Trust and Communication in a Doctor- Patient Relationship: Healthc Commun. 2018;vol.3(3:36):1-6.

\section{Tables}


Table 1: Sociodemographic characteristics of study participants at JMC, Ethiopia, 2020. ( $n=372)$ 


\begin{tabular}{|c|c|c|c|c|}
\hline № & Variable & Classification & Frequency & Percent \\
\hline \multirow[t]{6}{*}{1.} & \multirow[t]{6}{*}{ Age } & $18-27$ & 157 & 42.2 \\
\hline & & $28-37$ & 167 & 44.9 \\
\hline & & $38-47$ & 41 & 11.0 \\
\hline & & $>48^{+}$ & 7 & 1.9 \\
\hline & & Total & 372 & 100.0 \\
\hline & & Mean and SD & $29.5 \pm 3.5$ & \\
\hline \multirow[t]{4}{*}{2.} & \multirow[t]{4}{*}{ Education status } & No formal education & 81 & 21.8 \\
\hline & & Primary(1-8) & 121 & 32.5 \\
\hline & & Secondary (9-12) & 113 & 30.4 \\
\hline & & Diploma and above & 57 & 15.3 \\
\hline \multirow[t]{4}{*}{3.} & \multirow[t]{4}{*}{ Marital status } & Single & 50 & 13.4 \\
\hline & & Married & 310 & 83.3 \\
\hline & & Divorced & 9 & 2.4 \\
\hline & & Widowed & 3 & .8 \\
\hline \multirow[t]{4}{*}{4.} & \multirow[t]{4}{*}{ Religion } & Orthodox & 123 & 33.1 \\
\hline & & Protestant & 64 & 17.2 \\
\hline & & Muslim & 182 & 48.9 \\
\hline & & Other $^{1}$ & 3 & .8 \\
\hline \multirow[t]{5}{*}{5.} & \multirow[t]{5}{*}{ Ethnicity } & Oromo & 267 & 71.8 \\
\hline & & Amhara & 37 & 9.9 \\
\hline & & Tigre & 5 & 1.3 \\
\hline & & Gurage & 59 & 15.9 \\
\hline & & Other ${ }^{2}$ & 4 & 1.1 \\
\hline \multirow[t]{5}{*}{6.} & \multirow[t]{5}{*}{ Occupation } & Housewife & 168 & 45.2 \\
\hline & & Private employee & 33 & 8.9 \\
\hline & & Government employee & 68 & 18.3 \\
\hline & & Merchant & 29 & 7.8 \\
\hline & & Farmer & 56 & 15.1 \\
\hline
\end{tabular}




\begin{tabular}{|c|c|c|c|c|}
\hline & & Student & 18 & 4.8 \\
\hline \multirow[t]{2}{*}{7.} & \multirow[t]{2}{*}{ Residence } & Urban & 242 & 65.1 \\
\hline & & Rural & 130 & 34.9 \\
\hline \multirow[t]{6}{*}{8.} & \multirow[t]{6}{*}{ Monthly income } & $<500$ & 110 & 29.6 \\
\hline & & $501-1500$ & 65 & 17.5 \\
\hline & & $1501-2500$ & 71 & 19.1 \\
\hline & & $2501-3500$ & 43 & 11.6 \\
\hline & & $3501-4500$ & 22 & 5.9 \\
\hline & & $>4501$ & 61 & 16.4 \\
\hline
\end{tabular}

Table 2: patient related factors, Jimma Medical center, Oromia region, Ethiopia, $2020(n=372)$. 


\begin{tabular}{|c|c|c|c|c|}
\hline № & Variable & Category & Frequency & Percent \\
\hline \multirow[t]{4}{*}{1.} & \multirow[t]{4}{*}{ Parity } & Null & 14 & 3.8 \\
\hline & & One & 160 & 43.0 \\
\hline & & Two to four & 150 & 40.3 \\
\hline & & Greater than five & 48 & 12.9 \\
\hline \multirow[t]{2}{*}{2.} & \multirow[t]{2}{*}{ Type of surgery (Schedule of surgery) } & Elective & 95 & 25.5 \\
\hline & & Emergency & 277 & 74.5 \\
\hline \multirow[t]{5}{*}{3.} & \multirow[t]{5}{*}{ Reason of the operation done } & ${ }^{1}$ Gynecological benign tumor & 12 & 3.2 \\
\hline & & ${ }^{2}$ Gynecological cancer & 20 & 5.4 \\
\hline & & Fistula & 10 & 2.7 \\
\hline & & Related to pregnancy & 319 & 85.8 \\
\hline & & ${ }^{3}$ Pelvic organ prolapse & 11 & 3.0 \\
\hline \multirow[t]{4}{*}{4.} & \multirow[t]{4}{*}{ Previous medical history } & No & 330 & 88.7 \\
\hline & & DM & 6 & 1.6 \\
\hline & & Hypertension & 26 & 7.0 \\
\hline & & Other(anemia, PPH, AUB) & 10 & 2.7 \\
\hline \multirow[t]{2}{*}{5.} & \multirow[t]{2}{*}{ Previous surgical history } & Yes & 103 & 27.7 \\
\hline & & No & 269 & 72.3 \\
\hline \multirow[t]{2}{*}{6.} & \multirow[t]{2}{*}{ Number of operation done } & 1 & 60 & 58.3 \\
\hline & & $\geq 2$ & 43 & 41.7 \\
\hline
\end{tabular}

${ }^{1}$ Fibroma, Myoma, Adenoma, Adenomyosis. Endometriosis, polyps ...etc

${ }^{2}$ Cervical Ca (squamous cell carcinoma or adenocarcinoma) , Endometrial Ca, Ovarian Ca....etc

${ }^{3}$ Cystocele, Urethrocele, Uterine prolapse, Vaginal vault prolapse, Rectocele \& Enterocele

Table 3: Service related factors, Jimma Medical Center, Oromia region, Ethiopia, $2020(n=372)$. 


\begin{tabular}{|c|c|c|c|c|}
\hline № & Variable & Category & Frequency & Percent \\
\hline \multirow[t]{2}{*}{1.} & \multirow[t]{2}{*}{ Referred history } & Yes & 258 & 69.4 \\
\hline & & No & 114 & 30.6 \\
\hline \multirow[t]{2}{*}{2.} & \multirow{2}{*}{$\begin{array}{l}\text { Language of written informed } \\
\text { consent }\end{array}$} & Within mother tongue & 234 & 62.9 \\
\hline & & Deferred from mother tongue & 124 & 33.3 \\
\hline \multirow[t]{3}{*}{3.} & \multirow[t]{3}{*}{ Consent requested by } & Ob-gyn specialist & 44 & 11.8 \\
\hline & & General practitioner/resident & 302 & 81.2 \\
\hline & & Midwife/nurse & 26 & 7.0 \\
\hline \multirow[t]{4}{*}{4.} & \multirow[t]{4}{*}{ Timing of consent } & $\begin{array}{l}\text { The day before date of } \\
\text { surgery }\end{array}$ & 65 & 17.5 \\
\hline & & On the day of surgery & 87 & 23.4 \\
\hline & & Immediately before surgery & 208 & 55.9 \\
\hline & & On the operation table & 12 & 3.2 \\
\hline \multirow[t]{3}{*}{5.} & \multirow{3}{*}{$\begin{array}{l}\text { Time taken to provide informed } \\
\text { consent }\end{array}$} & Less than 5 minute & 231 & 62.1 \\
\hline & & 5 to 10 minute & 76 & 20.4 \\
\hline & & Greater than 10 minute & 65 & 17.5 \\
\hline \multirow[t]{2}{*}{6.} & \multirow[t]{2}{*}{ Timing taken to decision making } & Less than 1 hour & 343 & 92.2 \\
\hline & & Greater than 1 hour & 29 & 7.8 \\
\hline \multirow[t]{2}{*}{7.} & \multirow[t]{2}{*}{ Person signed on informed consent } & Self & 352 & 94.6 \\
\hline & & Parent/spouse & 20 & 5.4 \\
\hline
\end{tabular}

Table 4: Satisfaction of respondents to wards SIC, JMC, Oromia Region, Ethiopia, 2020. 


\begin{tabular}{|c|c|c|c|c|c|c|}
\hline № & Item & $\begin{array}{l}\text { Completely } \\
\text { dissatisfied }\end{array}$ & Dissatisfied & Neutral & Satisfied & $\begin{array}{l}\text { Completely } \\
\text { satisfied }\end{array}$ \\
\hline 1. & $\begin{array}{l}\text { The information } \\
\text { on indication of } \\
\text { operation }\end{array}$ & $26(7.0 \%)$ & $166(44.6 \%)$ & 13(3.5\%) & 124(33.3\%) & $43(11.6 \%)$ \\
\hline 2. & $\begin{array}{l}\text { The alternative of } \\
\text { operation }\end{array}$ & $28(7.5 \%)$ & $89(23.9 \%)$ & $163(43.8 \%)$ & 71(19.1\%) & $21(5.6 \%)$ \\
\hline 3. & $\begin{array}{l}\text { The chance to } \\
\text { express opinions }\end{array}$ & $25(6.7 \%)$ & $223(59.9 \%)$ & $12(3.2 \%)$ & $89(23.9 \%)$ & $23(6.2 \%)$ \\
\hline 4. & $\begin{array}{l}\text { The chance to ask } \\
\text { questions }\end{array}$ & $22(5.9 \%)$ & $210(56.5 \%)$ & $16(4.3 \%)$ & $95(25.5 \%)$ & $29(7.8 \%)$ \\
\hline 5. & $\begin{array}{l}\text { The amount of } \\
\text { information about } \\
\text { operation }\end{array}$ & $33(8.9 \%)$ & $150(40.3 \%)$ & $17(4.6 \%)$ & $131(35.2 \%)$ & $41(11.0 \%)$ \\
\hline 6. & $\begin{array}{l}\text { The information } \\
\text { was easy to } \\
\text { understand }\end{array}$ & $32(8.6 \%)$ & 133(35.8\%) & $13(3.5 \%)$ & $155(41.7 \%)$ & $39(10.5 \%)$ \\
\hline 7. & $\begin{array}{l}\text { The awareness on } \\
\text { benefit of } \\
\text { operation }\end{array}$ & $9(2.4 \%)$ & $49(13.2 \%)$ & $20(5.4 \%)$ & $210(56.5 \%)$ & $84(22.6 \%)$ \\
\hline 8. & $\begin{array}{l}\text { The awareness on } \\
\text { risk of operation }\end{array}$ & $10(2.7 \%)$ & $90(24.2 \%)$ & $156(41.9 \%)$ & $56(15.1 \%)$ & $60(16.1 \%)$ \\
\hline 9. & $\begin{array}{l}\text { Involvement of in } \\
\text { the discussion } \\
\text { about operation }\end{array}$ & $3(.8 \%)$ & $23(6.2 \%)$ & $13(3.5 \%)$ & $166(44.6 \%)$ & $167(44.9 \%)$ \\
\hline 10. & $\begin{array}{l}\text { Involvement in the } \\
\text { decision making } \\
\text { on operation }\end{array}$ & $7(1.9 \%)$ & $15(4.0 \%)$ & $11(3.0 \%)$ & 117(31.5\%) & $222(59.7 \%)$ \\
\hline
\end{tabular}

Table 5: Bivariate logistic regression of factors associated with patients' satisfaction on SIC 2020. 


\begin{tabular}{|c|c|c|c|c|c|c|}
\hline \multirow[t]{2}{*}{ № } & \multirow[t]{2}{*}{ Variable } & \multirow[t]{2}{*}{ Category } & \multicolumn{2}{|c|}{ Satisfaction status } & \multirow[t]{2}{*}{ COR 95\% Cl } & \multirow{2}{*}{$\begin{array}{l}\mathrm{P}- \\
\text { value }\end{array}$} \\
\hline & & & Satisfied & Dissatisfied & & \\
\hline \multirow[t]{4}{*}{1.} & \multirow[t]{4}{*}{ Age } & $18-27$ & 56 & 101 & 1 ** & \\
\hline & & $28-37$ & 82 & 85 & $\begin{array}{l}1.740 \\
(1.114- \\
2.717)\end{array}$ & .015 \\
\hline & & $38-47$ & 17 & 24 & $\begin{array}{l}1.278(.633- \\
2.578)\end{array}$ & .494 \\
\hline & & $>48+$ & 5 & 2 & $\begin{array}{l}4.509(.847- \\
24.001)\end{array}$ & .077 \\
\hline \multirow[t]{4}{*}{2.} & \multirow[t]{4}{*}{ Educational status } & $\begin{array}{l}\text { No formal } \\
\text { education }\end{array}$ & 37 & 44 & 1 ** & \\
\hline & & $\begin{array}{l}\text { Complete } \\
\text { elementary } \\
\text { school }\end{array}$ & 38 & 83 & $\begin{array}{l}.544 \\
(.304-.974)\end{array}$ & .041 \\
\hline & & $\begin{array}{l}\text { Complete } \\
\text { secondary school }\end{array}$ & 48 & 65 & $\begin{array}{l}.878(.494- \\
1.56)\end{array}$ & .658 \\
\hline & & $\begin{array}{l}\text { Diploma and } \\
\text { above }\end{array}$ & 37 & 20 & $\begin{array}{l}2.200 \\
(1.095- \\
4.421)\end{array}$ & .027 \\
\hline \multirow[t]{3}{*}{3.} & \multirow[t]{3}{*}{ Marital status } & Single & 26 & 24 & $1 * \star$ & \\
\hline & & Marriage & 128 & 182 & $\begin{array}{l}.649(.357- \\
1.182)\end{array}$ & .158 \\
\hline & & Widowed-divorce & 6 & 6 & $\begin{array}{l}.923(.262- \\
3.255)\end{array}$ & .901 \\
\hline \multirow[t]{2}{*}{4.} & \multirow[t]{2}{*}{ Residence } & Rural & 45 & 85 & $1 \star \star$ & \multirow[t]{2}{*}{.017} \\
\hline & & Urban & 115 & 127 & $\begin{array}{l}1.710 \\
(1.101- \\
2.658)\end{array}$ & \\
\hline \multirow[t]{5}{*}{5.} & \multirow[t]{5}{*}{ Occupation } & Housewife & 77 & 91 & $1 * \star$ & \\
\hline & & Private employee & 10 & 23 & $\begin{array}{l}.514(.230- \\
1.146)\end{array}$ & .104 \\
\hline & & $\begin{array}{l}\text { Government } \\
\text { employee }\end{array}$ & 38 & 30 & $\begin{array}{l}1.497(.849- \\
2.639)\end{array}$ & .163 \\
\hline & & Merchant & 12 & 17 & $\begin{array}{l}.834(.375- \\
1.855)\end{array}$ & .657 \\
\hline & & Farmer & 18 & 38 & $\begin{array}{l}.560(.296- \\
1.059)\end{array}$ & .075 \\
\hline
\end{tabular}




\begin{tabular}{|c|c|c|c|c|c|c|}
\hline & & Student & 5 & 13 & $\begin{array}{l}.455(.155- \\
1.332)\end{array}$ & .151 \\
\hline \multirow[t]{6}{*}{6.} & \multirow[t]{6}{*}{ Monthly income } & $<500$ & 49 & 61 & 1 & \\
\hline & & $501-1500$ & 23 & 42 & $\begin{array}{l}.682(.362- \\
1.283)\end{array}$ & .265 \\
\hline & & $1501-2500$ & 31 & 40 & $\begin{array}{l}.965(.529- \\
1.760)\end{array}$ & .907 \\
\hline & & $2501-3500$ & 15 & 28 & $\begin{array}{l}.667(.321- \\
1.386)\end{array}$ & .278 \\
\hline & & $3501-4500$ & 12 & 10 & $\begin{array}{l}1.494(.596- \\
3.747)\end{array}$ & .392 \\
\hline & & $>4501$ & 30 & 31 & $\begin{array}{l}1.205(.643- \\
2.256)\end{array}$ & .561 \\
\hline \multirow[t]{4}{*}{7.} & \multirow[t]{4}{*}{ Parity } & Null & 4 & 10 & 1 ** & \\
\hline & & 1 & 64 & 96 & $\begin{array}{l}1.667(.501- \\
5.544)\end{array}$ & .476 \\
\hline & & $2-4$ & 66 & 84 & $\begin{array}{l}1.964(.590- \\
6.545)\end{array}$ & .084 \\
\hline & & $>5$ & 26 & 22 & $\begin{array}{l}2.955(.812- \\
10.745)\end{array}$ & .405 \\
\hline \multirow[t]{2}{*}{8.} & \multirow[t]{2}{*}{ Type of surgery } & Emergency & 105 & 172 & $1 * \star$ & \multirow[t]{2}{*}{.001} \\
\hline & & Elective & 55 & 40 & $\begin{array}{l}2.252 \\
(1.402- \\
3.619)\end{array}$ & \\
\hline \multirow[t]{4}{*}{9.} & \multirow[t]{4}{*}{ Previous medical Hx } & No & 143 & 187 & 1 & \\
\hline & & DM & 3 & 3 & $\begin{array}{l}1.308(.260- \\
6.575)\end{array}$ & .745 \\
\hline & & HNT & 11 & 15 & $\begin{array}{l}.959(.427- \\
2.151)\end{array}$ & .919 \\
\hline & & Renal, anemia & 3 & 7 & $\begin{array}{l}.560(.142- \\
2.205)\end{array}$ & .407 \\
\hline \multirow[t]{2}{*}{10.} & \multirow[t]{2}{*}{$\begin{array}{l}\text { Previous Surgical } \\
\text { history }\end{array}$} & Yes & 48 & 55 & $\begin{array}{l}1.223(.775- \\
1.932)\end{array}$ & \multirow[t]{2}{*}{.387} \\
\hline & & No & 112 & 157 & 1 & \\
\hline \multirow[t]{2}{*}{11.} & \multirow{2}{*}{$\begin{array}{l}\text { Referred history from } \\
\text { other hospital }\end{array}$} & Yes & 103 & 155 & $1 * \star$ & \multirow[t]{2}{*}{.071} \\
\hline & & No & 57 & 57 & $\begin{array}{l}1.505(.966- \\
2.345)\end{array}$ & \\
\hline 12. & Language of written & Defer from & 40 & 84 & 1 ** & .009 \\
\hline
\end{tabular}


consent form

mother tongue

$\begin{array}{llll}\text { In mother tongue } & 109 & 125 & 1.831(1.161- \\ & & & 2.889)\end{array}$

13. Consent request by ob-gyn specialist 33

$33 \quad 11$

$\begin{array}{lll}1 & 4.800 & .003\end{array}$

$(1.690-$

13.634)

$\begin{array}{lllll}\text { GP or resident } & 117 & 185 & 1.012(.444- \\ & & & 2.305)\end{array}$

Midwives /nurse $10 \quad 16 \quad 1$ **

14. Timing of consent

the day before $\quad 45$

date of surgery

$45 \quad 20$

$3.150(.891-\quad .075$

11.136)

on the day of

surgery

33

$856(251-$

2.917)

immediately

before surgery

77

54

on the operation

table

15. Time spent to decide $<1$ hour

147

196

$.923(.431-$

$1.979)$

.837

$2.682)$

746

$\geq 1$ hour

13

16

1

16. Time spent to provided informed consent

5-10 minute

72

159

1 **

44

32

3.036

(1.781-

.001

5.178)

$>10$ minute

44

21

4.627

(2.566-

8.345)

17. who sign on informed consent form

$\begin{array}{ll}\text { Self } & 146 \\ \text { Parent/spouse } & 14\end{array}$

146

206

1 **

.017

14

6

3.292

(1.236-

8.768)

18. Knowledge to wards SIC

Poor knowledge
Good knowledge

1 **

.176

$1.399(.861-$

2.274)

19. Patient to healthcare provider relationship

$\begin{array}{llll}\text { Poor } & 47 & 146 & 1 \text { ** } \\ \text { Good } & 113 & 66 & 5.319 \\ & & & (3.400- \\ & & & 8.320)\end{array}$


Key: COR: crude odd ratio 1: Reference category ** candidate variable to multivariate logistic regression

Table 6: Multivariable logistic regression of factors associated with patients' satisfaction towards SIC, 2020.

\begin{tabular}{|c|c|c|c|c|c|c|}
\hline \multirow[t]{2}{*}{ № } & \multirow[t]{2}{*}{ Variable } & \multirow[t]{2}{*}{ Category } & \multicolumn{2}{|c|}{ Satisfaction status } & \multirow{2}{*}{$\begin{array}{l}\text { COR }(95 \% \\
\mathrm{Cl})\end{array}$} & \multirow{2}{*}{$\begin{array}{l}\text { AOR }(95 \% \\
\text { Cl) }\end{array}$} \\
\hline & & & Satisfied & Dissatisfied & & \\
\hline \multirow[t]{2}{*}{1.} & \multirow[t]{2}{*}{ Residence } & Rural & 45 & 85 & & 1 \\
\hline & & Urban & 115 & 127 & $\begin{array}{l}1.710 \\
(1.101- \\
2.658)\end{array}$ & $\begin{array}{l}2.279 \\
(1.257- \\
4.131)^{\star \star}\end{array}$ \\
\hline \multirow[t]{2}{*}{2.} & \multirow{2}{*}{$\begin{array}{l}\text { Referred history } \\
\text { from other health } \\
\text { facility }\end{array}$} & Yes & 103 & 155 & & 1 \\
\hline & & No & 57 & 57 & $\begin{array}{l}1.505(.966- \\
2.345)\end{array}$ & $\begin{array}{l}1.856 \\
(1.033- \\
3.337)^{\star}\end{array}$ \\
\hline \multirow[t]{2}{*}{3.} & \multirow[t]{2}{*}{$\begin{array}{l}\text { Language of written } \\
\text { consent form }\end{array}$} & $\begin{array}{l}\text { Defer from } \\
\text { mother } \\
\text { tongue }\end{array}$ & 40 & 84 & & 1 \\
\hline & & $\begin{array}{l}\text { With mother } \\
\text { tongue }\end{array}$ & 109 & 125 & $\begin{array}{l}1.831(1.161- \\
2.889)\end{array}$ & $\begin{array}{l}2.076 \\
(1.143- \\
3.773)^{\star}\end{array}$ \\
\hline \multirow[t]{3}{*}{4.} & \multirow{3}{*}{$\begin{array}{l}\text { Time spent while } \\
\text { provided SIC }\end{array}$} & $<5$ minute & 72 & 159 & & 1 \\
\hline & & 5-10 minute & 44 & 32 & $\begin{array}{l}3.036(1.781- \\
5.178)\end{array}$ & $\begin{array}{l}1.794(.887- \\
3.627)\end{array}$ \\
\hline & & $>10$ minute & 44 & 21 & $\begin{array}{l}4.627(2.566- \\
8.345)\end{array}$ & $\begin{array}{l}5.227 \\
(2.499- \\
10.936)^{\star \star}\end{array}$ \\
\hline \multirow[t]{2}{*}{5.} & \multirow{2}{*}{$\begin{array}{l}\text { Patient to health } \\
\text { care providers } \\
\text { relationship }\end{array}$} & Poor & 47 & 146 & & 1 \\
\hline & & Good & 113 & 66 & $\begin{array}{l}5.319 \\
(3.400- \\
8.320)\end{array}$ & $\begin{array}{l}5.419 \\
(3.103- \\
9.464)^{\star \star}\end{array}$ \\
\hline
\end{tabular}

Key: - COD: Crude Odd Ratio, AOD: Adjusted odd Ratio ** Significant at P-value $<0.01$ * Significant at pvalue at $<0.05$

\section{Figures}




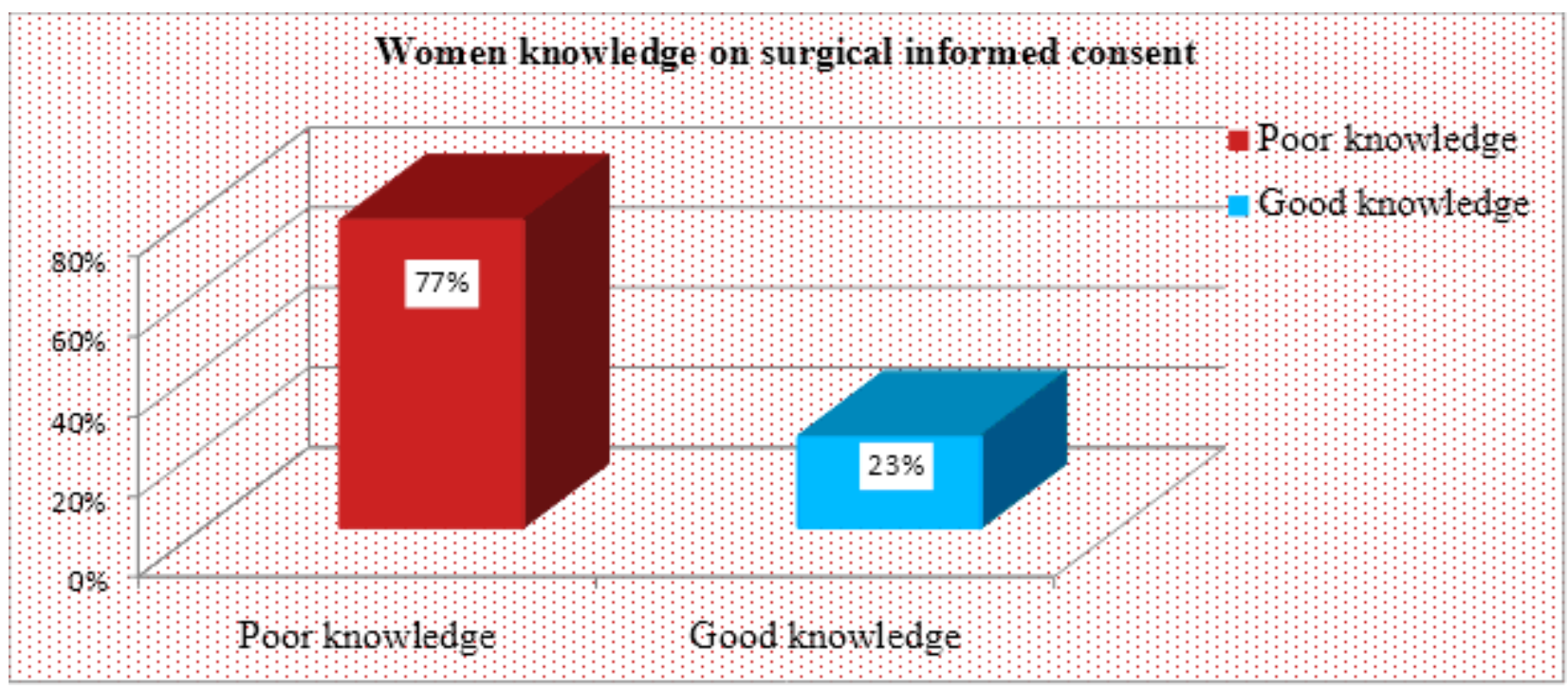

\section{Figure 1}

Women knowledge on surgical informed consent at Jimma Medical Center, Jimma, Oromia Region, Ethiopia 2020.

\section{Patent to Gedlthcare provider relations sh p status}

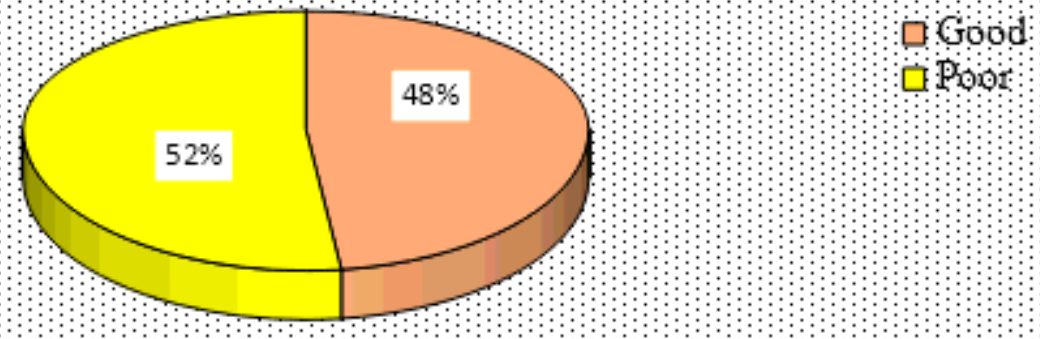

\section{Figure 2}

Patient to health care providers' relationship status at JMC, Jimma, Ethiopia, 2020. 


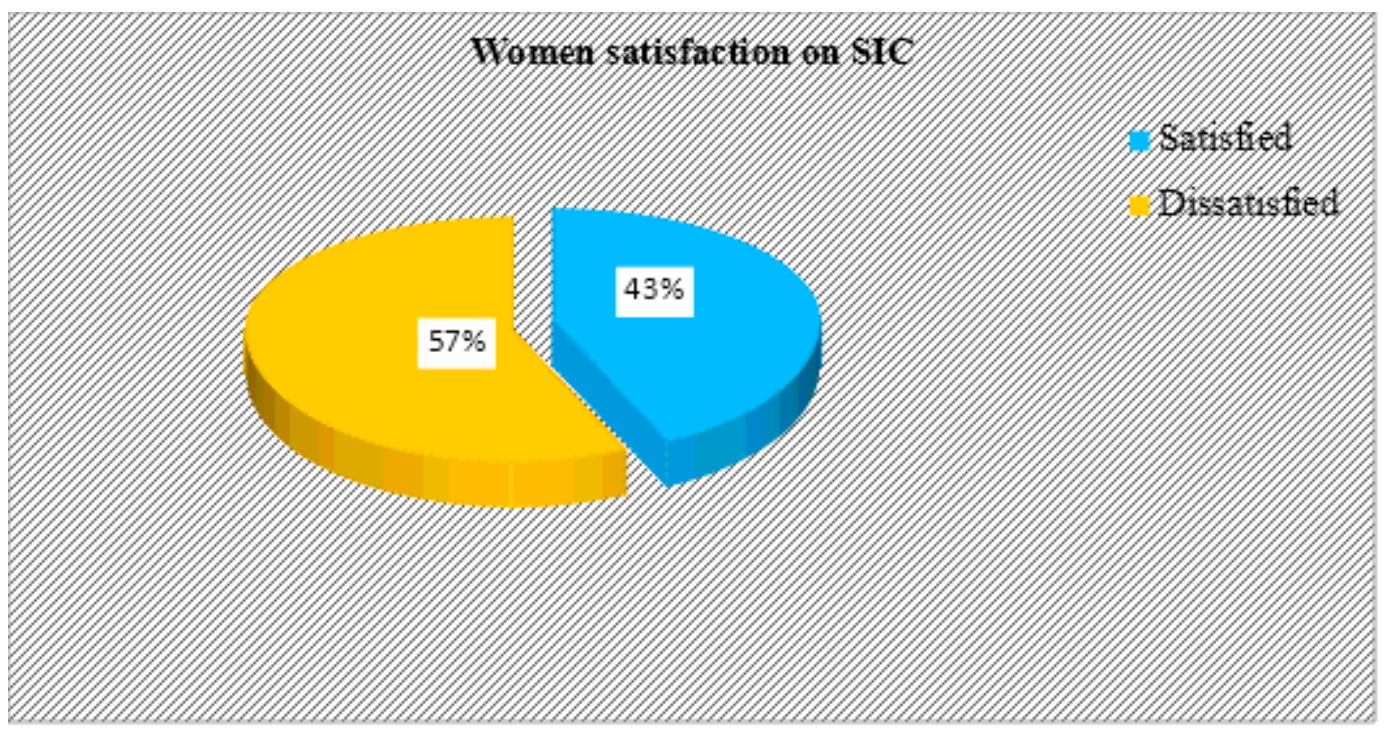

Figure 3

The overall mean satisfaction level of respondents on surgical informed consent at Jimma Medical center, Jimma, Ethiopia 2020. 